\title{
Vulvodynia - still a challenging therapeutic problem
}

\section{Wulwodynia - ciągle aktualne wyzwanie terapeutyczne}

\author{
Magdalena Pawlaczyk', Katarzyna Korzeniowska², Mariola Pawlaczyk ${ }^{3}$
}

'Laboratory of Neuropsychobiology, Department of Psychiatry, Poznan University of Medical Sciences in Poznan, Poland

2Division of Clinical Pharmacology, Chair of Cardiology, Poznan University of Medical Sciences in Poznan, Poland

${ }^{3}$ Division of Skin Disease Prophylaxis, Chair of Geriatrics and Gerontology, Poznan University of Medical Sciences in Poznan, Poland

'Pracownia Neuropsychobiologii Kliniki Psychiatrii Uniwersytetu Medycznego im. Karola Marcinkowskiego w Poznaniu, Polska ¿Zakład Farmakologii Klinicznej Katedry Kardiologii Uniwersytetu Medycznego im. Karola Marcinkowskiego w Poznaniu, Polska ${ }^{3}$ Zakład Profilaktyki Chorób Skóry Katedry Geriatrii i Gerontologii Uniwersytetu Medycznego im. Karola Marcinkowskiego w Poznaniu, Polska

\author{
CORRESPONDING AUTHOR/ \\ ADRES DO KORESPONDENCJI: \\ Magdalena Pawlaczyk \\ Pracownia Neuropsychobiologii \\ Klinika Psychiatrii \\ Uniwersytet Medyczny \\ im. Karola Marcinkowskiego \\ ul. Szpitalna 27/33 \\ 60-572 Poznań, Polska \\ tel.: +48601938423 \\ e-mail: p.magda.jm@gmail.com
}

\begin{abstract}
Introduction. Vulvodynia is a chronic condition characterized by pain and burning in the vulvar area without any abnormalities in clinical and laboratory examinations. The diagnosis is based on detailed assessment of medical history, physical examination and exclusion of other potential causes of vulvar pain. As yet, no definitive treatment algorithm has been universally accepted for vulvodynia.

Objective. To present a case of successful treatment of generalized spontaneous vulvodynia with low doses of amitriptyline.

Case report. A 42-year-old patient presented to a dermatology outpatient clinic with chronic generalized vulvar pain of 2 years' duration. She was diagnosed with generalized spontaneous vulvodynia. Amitriptyline treatment was introduced and supported by topical application of lignocaine gel. After 13 months of amitriptyline therapy a complete remission was achieved.

Conclusions. Vulvodynia is a complex disease with numerous presentations, the symptoms of which often overlap. Since the diagnosis of vulvodynia requires the exclusion of other abnormalities, it is fundamental to raise the awareness of the disease among clinicians, so as to enable early correct diagnosis and adequate treatment.
\end{abstract}

\section{STRESZCZENIE}

Wprowadzenie. Wulwodynia jest przewlekłą chorobą charakteryzującą się bólem i pieczeniem sromu przy braku jakichkolwiek nieprawidłowości w badaniach klinicznych i laboratoryjnych. Rozpoznanie opiera się na szczegółowej analizie historii choroby, badaniu fizykalnym i wykluczeniu innych czynników mogących wywoływać ból sromu. Dotychczas nie ustalono jednoznacznego algorytmu leczenia wulwodynii.

Cel pracy. Przedstawienie przypadku skutecznego leczenia wulwodynii samoistnej uogólnionej małymi dawkami amitryptyliny.

Opis przypadku. Pacjentka w wieku 42 lat zgłosiła się do poradni dermatologicznej z przewlekłym, uogólnionym bólem sromu trwającym 
od 2 lat. Postawiono diagnozę uogólnionej samoistnej wulwodynii. Wdrożono leczenie amitryptyliną wspomagane stosowanym miejscowo żelem z lignokainą. Po 13 miesiącach terapii amitryptyliną całkowicie ustąpiły dolegliwości.

Wnioski. Wulwodynia to złożona choroba występująca w różnych odmianach, których objawy często się nakładają. Rozpoznanie wymaga wykluczenia innych nieprawidłowości, dlatego ważne jest zwiększenie wiedzy klinicystów na temat wulwodynii, co umożliwi wczesne postawienie prawidłowej diagnozy oraz wdrożenie adekwatnego leczenia.

Key words: treatment, pain, vulva.

Słowa kluczowe: leczenie, ból, srom.

\section{INTRODUCTION}

Vulvodynia is a chronic condition which is characterized by vulvar pain persisting for over 3 months. It is diagnosed after excluding other potential causes of pain in the vulvar area - including dermatoses, inflammations, cancers, infections and neurological disorders [1]. The condition is characterized by pain of varying intensity, described by patients as burning, discomfort, stinging or stabbing [2]. Vulvar pain which cannot be attributed to any mechanical factors is typical for spontaneous (unprovoked) vulvodynia, whereas pain induced by mechanical factors accompanies provoked vulvodynia. The disease can also exhibit a mixed pattern [3]. Symptoms may involve the entire vulva, in which case generalized vulvodynia is diagnosed, or occur only in a limited area, which is a characteristic feature of localized vulvodynia [4]. The aetiology of the disease remains speculative. Hypotheses postulating the role of immune reactions, hormonal changes, history of urogenital infections or psychosomatic disorders in the emergence of the disease have not been verified yet [5]. Vulvodynia affects approx. 9-12\% of the general reproductive-age female population $[6,7]$. The foundation of diagnosis is detailed medical history of the patient, and lack of abnormalities on physical examination and in laboratory tests. The disease has been shown to significantly decrease the quality of life in affected patients, and have a severe adverse impact on their psychosocial and sexual functioning. It is not uncommon for women with vulvodynia to also suffer from depression, obsessive-compulsive and anxiety disorders [8,9]. There are, as yet, no definitive published guidelines for the therapeutic management of the condition, supported by randomized trials. Therefore, patient management varies depending on the type of the disease. Treatment strategies recommended in cases of spontaneous

\section{WSTĘP}

Wulwodynia jest przewlekłą chorobą charakteryzującą się bólem sromu utrzymującym się powyżej 3 miesięcy. Schorzenie rozpoznaje się po wykluczeniu innych przyczyn dolegliwości bólowych tej okolicy, takich jak dermatozy, stany zapalne, nowotwory, infekcje i choroby neurologiczne [1]. Cechuje się bólem o zmiennym nasileniu, określanym przez pacjentki jako palenie, dyskomfort, pieczenie lub kłucie [2]. Ból sromu odczuwany bez działania jakichkolwiek czynników mechanicznych charakteryzuje wulwodynię samoistną, natomiast ból indukowany czynnikami mechanicznymi towarzyszy wulwodynii prowokowanej. Wyróżnia się także odmianę mieszaną [3]. Dolegliwości mogą obejmować cały srom - wówczas rozpoznaje się wulwodynię uogólnioną - bądź lokalizować się na ograniczonym obszarze, co cechuje wulwodynię ograniczoną [4]. Etiologia choroby jest nieznana. Hipotezy postulujące udział reakcji immunologicznych, zmian hormonalnych, przebytych zakażeń dróg moczowo-płciowych czy zaburzeń psychosomatycznych w powstawaniu choroby nie znalazły dotychczas potwierdzenia [5]. Wulwodynia dotyka ok. 9-12\% kobiet w wieku rozrodczym [6, 7]. Podstawą rozpoznania jest szczegółowo zebrany wywiad, brak odchyleń w badaniu przedmiotowym oraz badaniach laboratoryjnych. Choroba znacząco obniża jakość życia, utrudniając codzienne funkcjonowanie w sferze seksualnej oraz psychospołecznej, i nierzadko współwystępuje z depresją, zaburzeniami obsesyjno-kompulsywnymi oraz zaburzeniami lękowymi $[8,9]$. Dotąd nie opublikowano jednoznacznych wytycznych dotyczących postępowania terapeutycznego, popartych badaniami z randomizacją. Postępowanie różni się w zależności od odmiany choroby. W przypadkach wulwodynii samoistnej zaleca się edukację pacjentek, stosowanie technik psy- 
vulvodynia include education of patients, psychotherapeutic techniques, systemic and topical pharmacological therapy, and dietary modifications [10].

\section{OBJECTIVE}

To report a case of successful treatment of vulvodynia with low doses of amitriptyline and topical lignocaine gel.

\section{CASE REPORT}

A 42-year-old patient presented to a dermatology outpatient clinic with generalized vulvar pain which had persisted for 2 years. The pain felt by the patient was of the burning type, and it occurred with varying intensity in different locations on the labia majora. In the evenings, the pain sensation made it difficult to fall asleep. Due to the symptoms the woman, previously sexually active, had abstained from sexual intercourse for the past year. The patient had no chronic diseases and took no medications on a permanent basis. She had regular menstrual cycles. She had given birth once, naturally. During the 12 months preceding her dermatology outpatient clinic appointment the woman was under the care of gynaecologists. Gynaecological examinations, however, failed to identify any deviations from the norm. The diagnostic process included assessment of vaginal microflora, cervical smear, transvaginal and abdominal ultrasound scan as well as histopathological examination of a vulvar tissue sample. No pathological lesions were found. Therapy prescribed to the patient consisted of topical antifungal, glucocorticosteroid and antibiotic-based medications, and oral fluconazole. Dermal examination ruled out diseases of the skin. Based on the patient's medical history, reported symptoms and the absence of skin lesions in the vulvar region, generalized spontaneous vulvodynia was diagnosed. The patient assessed the intensity of pain on a 10-point Numeric Rating Scale (NRS) as 9, and health-related quality of life using the Dermatology Life Quality Index (DLQI) [11] as 20. The nature of the disease was explained to the patient, and treatment was prescribed including mild emollient-containing feminine hygiene products, topical lignocaine (2\%) gel and systemic amitriptyline. The starting dose was $10 \mathrm{mg} /$ day. Since no improvement was noted and the drug was well-tolerated, the dose was increased to $35 \mathrm{mg} /$ day after 6 weeks and to $45 \mathrm{mg} /$ day after another 6 weeks. After 10 months, the subjective sensation of pain on the NRS scale decreased to 6 . At that point, topical treatment was discontinued. After another 3 months of amitriptyline therapy, the patient showed complete remission of pain, and the DLQI score was 2. Over the following month, the doses of the drug choterapeutycznych, farmakoterapię ogólną i miejscową oraz modyfikację diety [10].

\section{CEL PRACY}

Przedstawienie przypadku skutecznej terapii wulwodynii z zastosowaniem małych dawek amitryptyliny oraz miejscowo stosowanego żelu z lignokainą.

\section{OPIS PRZYPADKU}

Pacjentka 42-letnia zgłosiła się do poradni dermatologicznej z powodu uogólnionego bólu sromu trwającego od 2 lat. Ból o charakterze pieczenia obejmował ze zmiennym natężeniem różne miejsca na wargach sromowych większych, wieczorem utrudniał zasypianie. Z powodu tych dolegliwości kobieta, wcześniej aktywna seksualnie, od roku nie podejmowała współżycia. Nie chorowała przewlekle, nie przyjmowała leków na stałe, miesiączkowała regularnie, rodziła jeden raz siłami natury. W czasie ostatnich 12 miesięcy przed wizytą była pod opieką ginekologów. Badania ginekologiczne nie wykazywały odchyleń od stanu prawidłowego. W przebiegu procesu diagnostycznego wykonano ocenę mikrobiologiczną flory pochwy, badanie cytologiczne szyjki macicy, ultrasonografię transwaginalną oraz jamy brzusznej, a także badanie histopatologiczne wycinka ze sromu i nie stwierdzono zmian patologicznych. W terapii stosowano miejscowe leki przeciwgrzybicze, glikokortykosteroidy i antybiotyki oraz doustnie flukonazol. Badanie dermatologiczne wykluczyło choroby skóry. Ze względu na historię choroby i zgłaszane dolegliwości oraz brak zmian skórnych na sromie rozpoznano uogólnioną samoistną wulwodynię. Pacjentka określiła natężenie bólu na 9 w 10-stopniowej skali numerycznej (NRS), a jakość życia zależną od stanu zdrowia ocenioną kwestionariuszem wpływu dolegliwości skórnych na jakość życia (DLQI) [11] na 20. Po wyjaśnieniu istoty choroby zalecono stosowanie łagodnych środków myjących $z$ dodatkiem emolientów, miejscowo $2 \%$ lignokainę w żelu oraz ogólnie amitryptylinę. Terapię rozpoczęto od dawki $10 \mathrm{mg} /$ dobę. Po 6 tygodniach z powodu braku poprawy, przy dobrej tolerancji leku, zwiększono dawkę do $35 \mathrm{mg}$, a po kolejnych 6 tygodniach do $45 \mathrm{mg} /$ dobę. Po 10 miesiącach subiektywne odczucie bólu zmniejszyło się do 6 w skali NRS i wtedy wstrzymano leczenie miejscowe. Po następnych 3 miesiącach terapii amitryptyliną uzyskano całkowite ustąpienie dolegliwości bólowych, a wskaźnik DLQI wynosił 2. Przez kolejny miesiąc stopniowo zmniejszano dawki leku aż do całkowitego jego odstawienia. Podczas wizyty kontrolnej 
were gradually reduced until complete discontinuation. During the follow-up visit 7 months later, the patient reported no recurrence of pain.

\section{CONCLUSIONS}

Vulvodynia is diagnosed after the exclusion of all other potential causes of vulvar pain [1]. The etiopathogenesis of the disease is complex, and no effective therapeutic method has been established to date [12, 13]. Amitriptyline is one of the first drugs used in the pharmacological management of the disease, and its efficacy is estimated at $60-70 \%[5,14]$. Despite conflicting data regarding the efficacy of treatment based on tricyclic antidepressants $[10,15]$, the reported case shows that they can lead to complete remission of symptoms. The prerequisite for using amitriptyline is good tolerance of the drug. Adverse reactions accompanying the use of amitriptyline can result in drug discontinuation by patients, which complicates an objective assessment [16]. An important therapeutic factor is the education of patients, who should be provided with information about the nature of the disease and the time span required to achieve an improvement [2]. There are reports describing a beneficial effect of placebo on the clinical condition of patients [11]. Another possible therapeutic modality is physiotherapy. The most commonly used methods include pelvic floor muscle exercises, soft-tissue mobilization in the crotch area and relaxation techniques [17, 18]. To establish a correct diagnosis of vulvodynia, other abnormalities must be excluded. Consequently, it is essential to raise the awareness of the disease among clinicians, primarily gynaecologists and dermatologists who are typically the first medical practitioners to be visited by patients suffering from the condition. Early diagnosis increases the chance to introduce treatment producing at least partial relief of symptoms and reduce the risk of developing symptoms of depression and anxiety, and sexual dysfunction, among patients.

\section{CONFLICT OF INTEREST}

The authors declare no conflict of interest.
7 miesięcy później pacjentka nie zgłaszała nawrotów bólu.

\section{WNIOSKI}

Wulwodynię rozpoznaje się po wykluczeniu wszystkich innych przyczyn dolegliwości bólowych sromu [1]. Etiopatogeneza jest złożona i dotąd nie zdefiniowano skutecznej metody terapii [12, 13]. Amitryptylina jest jednym z pierwszych leków zastosowanych w farmakoterapii, o skuteczności określanej na poziomie $60-70 \%[5,14]$. Pomimo sprzecznych danych dotyczących efektywności terapii trójcyklicznymi lekami przeciwdepresyjnymi $[10,15]$ przedstawiony przypadek pokazuje, że mogą one prowadzić do całkowitej remisji objawów. Warunkiem zastosowania amitryptyliny jest jej dobra tolerancja. Działania niepożądane amitryptyliny mogą powodować odstawienie leku przez pacjentki, co utrudnia obiektywną ocenę [16]. Istotnym elementem terapii jest edukacja pacjentek - wyjaśnienie istoty choroby i uświadomienie, że potrzeba czasu na uzyskanie poprawy [2]. Opisywano korzystny wpływ placebo na poprawę stanu klinicznego chorych [11]. Fizjoterapia jest również wykorzystywana jako jedna z możliwości terapeutycznych. Do najczęściej stosowanych metod należą: ćwiczenia mięśni dna miednicy, ćwiczenia mobilizujące tkanki miękkie krocza oraz techniki relaksacyjne $[17,18]$. Prawidłowe rozpoznanie wulwodynii wymaga wykluczenia innych nieprawidłowości, dlatego ważne jest zwiększenie wiedzy klinicystów na temat tej choroby, przede wszystkim ginekologów i dermatologów, do których kobiety zgłaszają się najczęściej po raz pierwszy. Wczesne ustalenie rozpoznania zwiększa szanse wdrożenia leczenia pozwalającego na chociaż częściowe złagodzenie dolegliwości i zmniejsza ryzyko rozwoju objawów depresyjnych i lękowych, a także zaburzeń seksualnych u chorych.

\section{KONFLIKT INTERESÓW}

Autorzy deklarują brak konfliktu interesów.

\section{References}

Piśmiennictwo

1. Bornstein J., Goldstein A.T., Stockdale C.K., Bergeron S., Pukall C., Zolnoun D., et al.: 2015 ISSVD, ISSWSH, and IPPS consensus terminology and classification of persistent vulvar pain and vulvodynia. J Sex Med 2016, 13, 607-612.

2. Sadownik L.A.: Etiology, diagnosis, and clinical management of vulvodynia. Int J Womens Health 2014, 6, 437-449.

3. Haefner H.K.: Report of the International Society for the Study of Vulvovaginal Disease: terminology and classification of vulvodynia. J Low Genit Tract Dis 2007, 11, 48-49.

4. Petersen C.D., Lundvall L., Kristensen E., Giraldi A.: Vulvodynia. Definition, diagnosis and treatment. Acta Obstet Gynecol Scand 2008, 87, 893-901.

5. Pagano R.: Vulvodynia. [In:] Chronic pelvic pain. W. Ledger, W.D. Schlaff, T.G. Vancaillie (eds.), Cambridge University Press, Cambridge, 2015, 89-101.

6. Reed B.D., Harlow S.D., Sen A., Legocki L.J., Edwards R.M., Arato N., et al.: Prevalence and demographic characteristics of vulvodynia in a population-based sample. Am J Obstet Gynecol 2012, 206, 170e1-9. 
7. Harlow B.L., Kunitz C.G., Nguyen R.H.N., Rydell S.A., Turner R.M., MacLehose R.F.: Prevalence of symptoms consistent with a diagnosis of vulvodynia: population-based estimates from 2 geographic regions. Am J Obstet Gynecol 2014, 210, 40.e1-8.

8. Wylie K., Hallam-Jones R., Harrington C.: Psychological difficulties within a group of patients with vulvodynia. J Psychosom Obstet Gynaecol 2004, 25, 257-265.

9. Tribó M.J., Andión O., Ros S., Gilaberte M., Gallardo F., Toll A., et al.: Clinical characteristics and psychopathological profile of patients with vulvodynia: an observational and descriptive study. Dermatology 2008, 216, 24-30.

10. Andrews J.C.: Vulvodynia interventions - systematic review and evidence grading. Obstet Gynecol Surv 2011, 66, $299-315$.

11. Szepietowski J., Salomon J., Finlay A.Y., Klepacki A., Chodynicka B., Marionneau N., et al.: Wskaźnik wpływu dolegliwości skórnych na jakość życia - Dermatology Life Quality Index (DLQI): polska wersja językowa. Dermatol Klin 2004, 6, 63-70.

12. Reed B.D., Harlow S.D., Sen A., Edwards R.M., Chen D., Haefner H.K.: Relationship between vulvodynia and chronic comorbid pain conditions. Obstet Gynecol 2012, 120, 145-151.

13. Khandker M., Brady S.S., Vitonis A.F., MacLehose R.F., Stewart E.G., Harlow B.L.: The influence of depression and anxiety on risk of adult onset vulvodynia. J Womens Health 2011, 20, 1445-1451.

14. McKay M.: Dysesthetic ("essential") vulvodynia. Treatment with amitriptyline. J Reprod Med 1993, 38, 9-13.

15. Goldstein A.T., Pukall C.F., Brown C., Bergeron S., Stein A., Kellogg-Spadt S.: Vulvodynia: assessment and treatment. J Sex Med 2016, 13, 572-590.

16. Reed B.D., Caron A.M., Geronflo D.W., Haefner H.K.: Treatment of vulvodynia with tricyclic antidepressants: efficacy and associated factors. J Low Genit Tract Dis 2006, 10, 245-251.

17. Pasek J., Sieroń A., Nowosad M., Błaziak L.: Wybrane metody fizjoterapeutyczne w leczeniu dysfunkcji mięśni miednicy u kobiet. Rehabilitacja w Praktyce 2014, 3, 24-27.

18. Backman H., Widenbrant M., Bohm-Starke N., Dahlof L.G.: Combined physical and psychosexual therapy for provoked vestibulodynia - an evaluation of a multidisciplinary treatment model. J Sex Res 2008, 45, 378-385.

Received: 22.01 .2017

Accepted: 3.03.2017

Otrzymano: $22.01 .2017 \mathrm{r}$.

Zaakceptowano: 3.03 .2017 r.

How to cite this article

Pawlaczyk M., Korzeniowska K., Pawlaczyk M.: Vulvodynia - still a challenging therapeutic problem. Dermatol Rev/Przegl Dermatol 2017, 104, 128-132. DOI: https:/ / doi.org/10.5114/dr.2017.67387 